\title{
UPAYA PENANGGULANGAN PENYEBARAN WABAH NOVEL CORONAVIRUS DISEASE (Covid-19) DI KELURAHAN TANJUNG AGUNG KECAMATAN SUNGAI SERUT KOTA BENGKULU
}

\author{
Rumyta Shandrah ${ }^{1}$, Hesti Pujiwati ${ }^{2}$
}

\footnotetext{
${ }^{1}$ Fakultas Matematika dan IImu Pengetahuan Alam, Universitas Bengkulu, Bengkulu, Indonesia

${ }^{2}$ Fakultas Pertanian, Universitas Bengkulu, Bengkulu, Indonesia

E-mail: hesti_pujiwati@unib.ac.id

Received September 2020, Accepted October 2020
}

\begin{abstract}
ABSTRAK
Akhir-akhir ini masyarakat dunia tengah diguncang dengan virus yang sudah ditetapkan menjadi pandemi dunia, ialah novel coronavirus disease 2019 (Covid-19). Maka dari itu, program kerja yang diusulkan pada KKN Mandiri UNIB 91 ini berfokus pada membantu pemerintah untuk memaksimalkan upaya pencegahan penyebaran lebih luas. Metode pelaksanaan KKN Mandiri UNIB 91 ini sudah dilakukan secara berkala selama 5 minggu dan disebarluaskan melalui media sosial serta mengirimkan kepada masyarakat Kelurahan Tanjung Agung. Pelaksanaannya mulai dari persiapan hingga laporan mingguan yang dilaporkan setiap akhir pekan. Luaran yang dihasilkan dari program kerja yang diusulkan berupa masyarakat bisa paham protokol kesehatan penanganan Covid-19 serta bagaimana cara meningkatkan imunitas tubuh. Selain itu, akan ada produk berupa empat video, tiga leaflet dan tiga puluh bungkus jahe instan yang akan dibagikan ke warga Kelurahan Tanjung Agung Kota Bengkulu.
\end{abstract}

Kata Kunci : Covid-19, Pengabdian, Protokol, Pencegahan, Kesehatan

\section{ABSTRACT}

\section{EFFORTS TO CONTROL THE SPREAD OF THE NOVEL CORONAVIRUS DISEASE (Covid-19) PLANE IN TANJUNG AGUNG SUB-DISTRICT, SUNGAI SERUT DISTRICT, BENGKULU CITY.} Recently, the world community is being shaken by a virus that has been declared a world pandemic, namely the novel coronavirus disease 2019 (Covid-19). Therefore, the proposed work program at the UNIB 91 Mandiri $K K N$ focuses on helping the government to prevent wider spread. The method of implementing KKN Mandiri UNIB 91 is carried out regularly for 5 weeks and disseminated through social media and sending to the community of Tanjung Agung Village. The implementation starts from preparation to weekly reports which are reported every weekend. The output resulting from the proposed work program is that the public can understand the health protocol for handling Covid-19 and how to increase 
immunity. In addition, there will be products in the form of four videos, three leaflets and thirty packs of instant ginger which will be distributed to residents of Tanjung Agung Village, Bengkulu City.

Keywords : Covid-19, Community Service, Protocol, Prevention, Health

\section{PENDAHULUAN}

Belakangan ini, Indonesia bahkan dunia diresahkan oleh kehadiran virus corona. Virus yang sudah meresahkan semua elemen masyarakat karena keganasannya yang bisa mengakibatkan kematian.. Meskipun demikian, banyak masyarakat yang tidak mengikuti protokol kesehatan sesuai anjuran pemerintah, hampir seluruh masyarakat tidak mengikuti protokol kesehatan yang disampaikan oleh pemerintah dan ini disebabkan beberapa hal sebagai berikut: 1) Disebabkan faktor kebutuhan, masyarakat memilih bekerja di luar rumah dibanding tetap tinggal dirumah; 2) Sulit mendapatkan masker; 3) Adanya kebiasaan tidak betah tinggal dirumah; 4) Adanya persepsi bahwa virus corona belum menyebar di wilayah tempat tinggalnya.

Ketika masyarakat tidak mengikuti anjuran pemerintah yang disebabkan oleh beberapa hal diatas, berarti mereka tidak melakukan gerakan pencegahan penyebaran virus COVID-19. Bila gerakan pencegahan tidak dilakukan artinya ini akan mempercepat proses penyebaran virus, dan protokol kesehatan yang disampaikan oleh pemerintah pun tidak akan efektif sebab masyarakat tidak mengimplementasikannya dalam kehidupan sehari-hari (Zendrato, 2020)

Kuliah kerja nyata (KKN) merupakan perwujudan pengabdian pada masyarakat yang terkandung pada salah satu dharma perguruan tinggi, yakni pengabdian kepada masyarakat yang bersifat lintas disiplin (interdisipliner) dan merupakan komponen keilmuan, teknologi dan seni secara aplikatif guna membantu kehidupan masyarakat, terutama di pedesaan. Melalui KKN ini para mahasiswa dapat membantu masyarakat dalam menghadapi kesulitan-kesulitan yang dihadapi masyarakat sesuai dengan bidang keilmuan masing-masing.

Kuliah kerja nyata secara mandiri juga memiliki peran dan tanggung jawab social dalam permasalahan yang sedang dihadapi bangsa dan masyarakat saat ini. Seperti yang kita ketahui bersama, bahwa covid-19 sedang menjadi permasalahan utama di dunia, salah satunya Indonesia. Sejak Desember 2019 pandemi Covid-19 telah melanda dunia. Sejak dilaporkan kasus pertama di Indonesia pada 2 maret 2020 pandemi berbahaya ini telah meresahkan seluruh masyarakat. Sejak saat itu, setiap hari kasus yang terkonfirmasi terus bertambah. Dan pada pelaporan terakhir pada tanggal 3 Juni 2020 kasus yang terkonfirmasi positif diseluruh Indonesia telah mencapai 28.233 orang, dan yang sembuh sudah 8.406 dan meninggal 1.698 orang.

Sudah banyak upaya yang telah dilakukan pemerintah dalam mencegah wabah ini. Mulai dari pembelajaran di sekolah dan di kampus yang telah dipindahkan di rumah masing-masing. Bekerja di rumah bagi 
pegawai dan pembatasan sosial berskala besar serta meminta seluruh warga untuk tetap menjaga diri dari wabah ini. Tapi banyak dari warga yang masih belum paham tentang wabah ini. Masih banyak yang beraktivitas diluar rumah. Sehingga kasus positif makin hari makin bertambah.

Minimnya pengetahuan dan kewaspadaan masyarakat tentang virus ini menyebabkan semakin hari bertambah dengan signifikan korban yang berjatuhan Sehingga, atas dasar tersebut peserta KKN MANDIRI UNIB 91 haruslah memiliki solusi untuk meminimalisirkan jumlah korban.

Adapun bidang kegiatan yang akan diambil pada pelaksanaan KKN MANDIRI UNIB 91 ini ialah mengenai bidang kesehatan dan kebersihan lingkungan serta bidang perekonomian dan produksi. Tujuan dari diangkatnya kedua bidang tersebut karena minimnya pengetahuan masyarakat sekitar untuk bidang kesehatan dan kebersihan. Sehingga, saat masyarakat menerima kegiatan ini, harapannya tingkat pengetahuan masyarakat dapat bertambah.

Sementara itu, untuk bidang perekonomian dan produksi adalah untuk mengedukasi masyarakat agar dapat memanfaatkan tanaman obat keluarga yang bisa meningkatkan imunitas tubuh. Pada bidang ini, tanaman obat keluarga yang akan diambil adalah jahe yang dibuat menjadi jahe instan.

Program-progjam kerja yang sudah dilakukan berdampak pada perilaku warga sekitar. Banyak dari warga yang sudah mulai menerapkan protokol-protokol yang sudah diusungkan. Beberapa warga yang belum menerapkannya sudah diajak berbincang oleh peserta KKN Mandiri dengan memberitahu dampak karena adanya virus ini.

\section{MATERI DAN METODE}

Pelaksanaan kegiatan Kuliah Kerja Nyata Mandiri Periode 91 Universitas Bengkulu ini dilakukan di Kelurahan Tanjung Agung Kota Bengkulu dalam kurun waktu lima minggu. Bahan-bahan yang digunakan ialah jahe, gula, plastik pembungkus, serai, kayu manis, kapulaga, sabun cuci tangan, masker kain dan leaflet. Alat-alat yang digunakan ialah kamera telepon, tripod, wajan, sutil, blender, pisau, talenan, sendok dan baskom.

Empat video diambil dalam empat minggu yang berbeda. Minggu pertama adalah video cara mencuci tangan menurut anjuran WHO. Minggu kedua adalah video cara mencuci tangan yang benar. Minggu ketiga adalah video mengenai protokol New Normal. Minggu keempat adalah video tutorial pembuatan jahe merah instan. Video-video tersebut kemudian diedit menggunakan aplikasi filmorago dan inshot. Setelah video diedit, kemudian diunggah ke kanal youtube, instagram, facebook dan whatsapp.

Selain pembuatan video juga dilakukan pembuatan jahe intan dengan menyiapkan jahe merah yang ingin digunakan, membersihkan jahe, setelah itu dicuci. Meniriskan dan memotong menjadi beberapa bagian. Kemudian diblender dan ditambahkan air secukupnya. Jahe yang 
sudah di blender kemudian disaring. Air jahe yang telah didapatkan dimasukan kedalam wajan atau panci yang sudah siap. Setelah itu dimasak dan ditambahkan dengan gula pasir, kayu manis, kapulaga dan serai. Diaduk sampai mendidih dan memadai sampai menjadi jahe instan yang diinginkan. Jahe instan dikemas dengan kemasan yang sudah disediakan.

\section{HASIL DAN PEMBAHASAN}

Dunia saat ini tengah waspada dengan penyebaran sebuah virus yang dikenal dengan virus corona. Coronaviruses (CoV) merupakan bagian dari keluarga virus yang menyebabkan penyakit mulai dari flu hingga penyakit yang lebih berat seperti Middle East Respiratory Syndrome (MERS-CoV) and Severe Acute Respiratory Syndrome (SARSCoV). Penyakit yang disebabkan virus corona, atau dikenal dengan COVID-19, adalah jenis baru yang ditemukan pada tahun 2019 dan belum pernah diidentifikasi menyerang manusia sebelumnya (World Health Organization, 2019).

Karena penularan virus corona yang sangat cepat inilah Organisasi Kesehatan Dunia (WHO) menetapkan virus corona sebagai pandemi pada 11 Maret 2020. Status pandemi atau epidemi global menandakan bahwa penyebaran COVID-19 berlangsung sangat cepat hingga hampir tak ada negara di dunia yang dapat memastikan diri terhindar dari virus corona (Widiyani, 2020).

Virus corona merupakan pandemi yang mudah menyebar secara contagious. Karena itu, banyak pemimpin yang menghimbau warganya untuk melakukan social distancing dan isolasi untuk mencegah penularan virus penyakit ini. Dalam jaringan sosial, banyak hal dapat menyebar secara contagious, termasuk virus. Dan cara untuk mencegah penyebaran makin luas adalah dengan menjalani peran sebagai isolate dalam jaringan sosial (Mona, 2020).

Merebaknya pandemi covid-19 di Indonesia membuat beberapa elemen masyarakat panik. Banyak dari masyarakat yang mengupayakan hal-hal yang bisa menghindari mereka terjangkit pandemi tersebut. Mulai dari cuci tangan, memakan makanan yang bergizi, melakukan physical distancing, tetap di rumah saja, dan lain halnya. Akan tetapi, pada masyarakat di Desa Tanjung Agung Kecamatan Sungai Serut Kota Bengkulu masih banyak yang melanggar beberapa protokol kesehatan yang dianjurkan. Salah satunya ialah mencuci tangan dan tidak menggunakan masker dengan baik dan benar. Sehingga perlu diadakan sosialisasi bagaimana penting dan cara cuci tangan tersebut, serta bagaimana menggunakan masker yang benar.

Selain itu, banyak pekerja di Desa Tanjung Agung yang tetap bekerja dengan alasan yang krusial, salah satunya karena masyarakat banyak yang memiliki ekonomi yang rendah. Atas alasan itulah mereka harus tetap bekerja di tengah pandemi covid-19 ini. Untuk itu, perlulah memberitahukan kepada masyarakat untuk tetap menjaga imun dan kekebalan tubuhnya agar tidak terjangkit. Salah satu cara untuk 
meningkatkan imun tubuh adalah dengan mengkonsumsi jahe yang bisa membuat tubuh hangat. Maka dari itu, dibuat video tutorial produksi jahe instan agar dapat diseduh kapanpun. Selain itu, jahe instan yang dihasilkan juga dapat dijual kembali oleh masyarakat.

Tabel 1. Kegiatan Kuliah Kerja Nyata Selama Lima Minggu

\begin{tabular}{|c|c|c|c|c|}
\hline No. & Lokas & & Aktivitas & Target \\
\hline 1. & $\begin{array}{l}\text { Kelurahan } \\
\text { Tanjung } \\
\text { Agung } \\
\text { Bengkulu }\end{array}$ & Kota & $\begin{array}{l}\text { Pembuatan video } \\
\text { cara mencuci tangan } \\
\text { menurut anjuran } \\
\text { WHO }\end{array}$ & $\begin{array}{l}\text { Masyarakat Kelurahan } \\
\text { Tanjung Agung }\end{array}$ \\
\hline 2. & $\begin{array}{l}\text { Kelurahan } \\
\text { Tanjung } \\
\text { Agung } \\
\text { Bengkulu } \\
\text { Kelurahan }\end{array}$ & Kota & $\begin{array}{l}\text { Pembuatan video } \\
\text { cara menggunakan } \\
\text { Masker yang benar }\end{array}$ & $\begin{array}{l}\text { Masyarakat Kelurahan } \\
\text { Tanjung Agung }\end{array}$ \\
\hline 3. & $\begin{array}{l}\text { Tanjung } \\
\text { Agung } \\
\text { Bengkulu }\end{array}$ & Kota & $\begin{array}{l}\text { Pembuatan video } \\
\text { protokol New Normal }\end{array}$ & $\begin{array}{l}\text { Masyarakat Kelurahan } \\
\text { Tanjung Agung }\end{array}$ \\
\hline 4. & $\begin{array}{l}\text { Kelurahan } \\
\text { Tanjung } \\
\text { Agung } \\
\text { Bengkulu } \\
\text { Kelurahan }\end{array}$ & Kota & $\begin{array}{l}\text { Pembuatan video } \\
\text { tutorial pembuatan } \\
\text { jahe merah instan }\end{array}$ & $\begin{array}{l}\text { Masyarakat Kelurahan } \\
\text { Tanjung Agung }\end{array}$ \\
\hline 5. & $\begin{array}{l}\text { Tanjung } \\
\text { Agung } \\
\text { Bengkulu }\end{array}$ & Kota & $\begin{array}{l}\text { Distribusi jahe merah } \\
\text { instan }\end{array}$ & $\begin{array}{l}\text { Masyarakat Kelurahan } \\
\text { Tanjung Agung }\end{array}$ \\
\hline
\end{tabular}

Dalam mencegah virus corona, salah satu cara yang dianjurkan oleh WHO adalah dengan mencuci tangan sesering mungkin. Cara mencuci tangannya ialah sebagai berikut: Telapak Tangan, cara cuci tangan yang pertama adalah dengan menggosok kedua telapak tangan. Telapak tangan adalah bagian tubuh pertama yang bertemu dengan benda lain. Jika tidak dibersihkan, kuman di telapak tangan bisa berkembang. Telapak dan punggung tangan, cara cuci tangan bisa Anda lanjutkan dengan menggosok telapak tangan kiri ke punggung tangan kanan. Hal yang sama juga berlaku sebaliknya. Kaitkan jari, setelah mencuci telapak dan punggung tangan, sela-sela jari juga jangan luput untuk Anda bersihkan. Kaitkan jemari dan gosok telapak tangan biar bersih. Punggung jari, agar cara cuci tangan semakin maksimal, pastikan untuk membersihkan punggung jari. Gosok punggung jari dengan arah memutar di atas telapak tangan. Jempol, karena jaraknya yang agak berjauhan dengan jari lain, maka jempol perlu Anda bersihkan secara terpisah. Caranya, dengan menggenggam jempol kanan dengan tangan kiri. Kemudian, gosok dengan arah memutar. Hal yang sama juga berlaku untuk jempol kiri. Kuku, kuku menjadi tempat bersarang kuman. Kuncupkan jemari, kemudian gosok di telapak tangan. Langkah ini akan 
lebih efektif jika kuku tidak panjang atau sering Anda potong. Setelah mencuci tangan dengan sabun, bilas menggunakan air bersih. Jangan lupa untuk mengeringkan tangan yang sudah Anda cuci (Biananda, 2020).

Dari hasil penelitian, masker kain hanya memiliki efektivitas menangkal virus Corona sebesar 70 persen. Dengan demikian, masyarakat diharapkan tetap jaga jarak saat di keramaian minimal 1-2 meter (Ade, 2020).

Dalam mencegah penularan virus corona, dokter Reisa Broto Asmoro seorang Dokter Umum menyampaikan bahwa semua orang harus menjaga gaya hidup bersih dan sehat, makanan yang seimbang, istrahat yang cukup, rutin olahraga, jangan panik dan stres agar daya tahan tubuh tidak menurun dan melakukan banyak kegiatan positif didalam rumah. Dokter Tirta Mandira Hudi seorang Dokter Relawan menyampaikan bahwa ketika berpergian dan pulang kerumah yang dilakukan pertama kali bukan salim atau cipika/cipiki tetapi mencuci tangan, muka, dan yang lainnya terlebih dahulu. Dokter Tirta juga mneyampaikan bahwa seluruh masyarakat menjaga pola hidup sehat, tetap dirumah saja (Kompas, 2020).

Salah satu cara untuk mencegah terinfeksi virus corona adalah dengan meningkatkan daya tahan tubuh atau sistem imun tubuh. Pada dasarnya, tubuh manusia memiliki sistem imun untuk melawan virus dan bakteri penyebab penyakit. Namun, ada hal-hal yang dapat melemahkan sistem imun atau daya tahan tubuh seseorang seperti penuaan, kurang gizi, penyakit, bahkan obat-obatan tertentu. Oleh karena itu, fungsi sistem imun perlu senantiasa dijaga agar daya tahan tubuh kuat. Beberapa cara yang dapat dilakukan untuk meningkatkan imun tubuh adalah mengonsumsi makanan bergizi, berolahraga dengan rutin, mengelola stres dengan baik, beristirahat yang cukup, meongonsumsi suplemen penunjang daya tahan tubuh (Nareza, 2020).

Guru Besar Fakultas Kedokteran, Kesehatan Masyarakat, dan Keperawatan (FKKMK) UGM, Prof.dr. Madarina Julia, Sp.A(K),MPH.,Ph.D., mengatakan bahwa tubuh manusia memerlukan sinar matahari untuk membantu meningkatkan produksi vitamin D didalam tubuh. Vitamin D ini punya efek imunomodulator yang bisa memperbaiki sistem imun tubuh, sistem imun merupakan pertahanan tubuh dalam melawan virus dan bakteri penyebab penyakit. Sementara itu, jika tubuh kekurangan vitamin $D$ dapat menghambat pertumbuhan dan rentan terinfeksi virus maupun bakteri, Prof. Mardiana menyampaikan waktu yang tepat untuk berjemur guna mendapatkan paparan sinar matahari yang cukup bisa dimulai dari jam 10.00 sampai 15.00, jangan dilakukan lebih pagi karena paparan sinar mataharinya tidak mencukupi[9].

Jahe (Zingiber officinale) merupakan tanaman rempah yang berasal dari Asia Selatan, dan sekarang telah tersebar ke seluruh dunia. Masyarakat China telah memanfaatkan jahe sebagai penyedap makanan sejak abad ke 6 S.M., dan para pedagang Arab telah mengenalkan jahe dan rempah-rempah lainnya sebagai bumbu masakan ke kawasan Mediterania sebelum abad pertama Sesudah Masehi, dan selanjutnya dikenalkan ke Eropah berupa buku-buku resep masakan yang 
menggunakan berbagai rempahrempah. Di Yunani, jahe digunakan pertama kali sebagai obat herbal untuk mengatasi penyakit vertigo, mualmual, dan mabuk perjalanan (Goulart, 1995).

Jahe sangat efektif untuk mencegah atau menyembuhkan berbagai penyakit karena mengandung gingerol yang bersifat antiinflamasi dan antioksidan yang sangat kuat. Lebih lanjut dinyatakan bahwa jahe berkhasiat untuk mengatasi berbagai penyakit, seperti mual-mual pada saat wanita sedang hamil, mengurangi rasa sakit dan nyeri otot, membantu menyembuhkan penyakit osteoarthritis, menurunkan kadar gula darah pada pasien yang menderita diabetes tipe 2 yang sekaligus menurunkan risiko penyakit jantung, membantu mengatasi gangguan pencernaan kronis, mengurangi rasa sakit saat wanita sedang menstruasi, menurunkan kadar kolesterol jahat (LDL) dan trigliserida dalam darah, membantu mencegah penyakit kanker (karena aktivitas 6-gingerol) terutama kanker pancreas, payudara dan kanker ovarium, meningkatkan fungsi otak dan mengatasi penyakit Alzheimer, dan membantu mengatasi risiko serangan berbagai penyakit infeksi (Leach, 2017).

Kandungan senyawa kimia aktif gingerol, zingeron, shogaol, gingerin dan zingerberin dalam jahe merah menyebabkan jahe merah memiliki khasiat yang besar untuk kesehatan seperti: menurunkan berat badan, menjaga kesehatan jantung, mengatasi mabuk kendaraan, mengatasi masalah pencernaan, meredakan penyakit mual dan muntah pada wanita yang sedang hamil, mencegah kanker usus, mengobati sakit kepala dan alergi, memperbaiki sistem kekebalan tubuh, dan mengatasi penyakit terkait dengan gangguan tenggorokan(Anon, 2018).

Jahe memiliki sifat anti-histamin yang biasa dimanfaatkan untuk menyembuhkan stres, alergi, kelelahan, dan sakit kepala, mengatasi gangguan tenggorokan, rasa mual saat mabuk laut, dan mengobati efek samping dari kemoterapi. Di samping itu, jahe juga mempunyai sifat antiinflamasi sehingga baik untuk mengobati radang sendi dan berbagai gangguan otot, menurunkan kadar kolesterol jahat, dan menjaga kesehatan jantung (Suparyo, 2014).

Luaran yang dihasilkan dari program kerja yang sudah dilaksanakan berbentuk video dan leaflet mengenai kesehatan dan kebersihan lingkungan, di antaranya adalah video dan leaflet cara cuci tangan yang benar pada minggu pertama (diunggah pada tanggal 27 Juni 2020), video penggunaan masker yang baik dan benar pada minggu ke dua (diunggah pada tanggal 4 Juli 2020) serta video dan leaflet protokol new normal pada minggu ke tiga (diunggah pada tanggal 11 Juli 2020).

Selain itu, luaran yang dihasilkan dari program kerja mengenai bidang perekonomian dan produksi, di antaranya adalah produk berupa jahe instan yang akan dibagikan serta video tutorial (diunggah pada tanggal 24 Juli 2020) pembuatannya yang akan diunggah pada media sosial agar dapat diakses oleh masyarakat umum yang dilakukan pada minggu ke empat dan ke lima.

Sehingga, luaran yang dihasilkan berbentuk empat video, tiga leaflet dan tiga puluh bungkus produk jahe instan yang akan dibagikan ke warga Desa Tanjung Agung Kota Bengkulu. Produk-produk jahe instan 
sudah dibagikan kepada warga sekitar Desa Tanjung Agung Kota Bengkulu.

\section{KESIMPULAN}

Pembuatan dan penyebarluasan video edukasi mengenai protokol kesehatan di masa pandemi Covid-19 sudah dilakukan, di antaranya adalah video cara mencuci tangan, cara menggunakan masker, protokol menjalani New Normal dan tutorial pembuatan jahe merah instan. Cukup banyak warga yang sudah mengerti bagaimana upaya untuk menanggulangi penyebaran virus corona. Jahe merah instan yang dihasilkan dapat dinikmati oleh warga sekitar dan warga sekitar bisa membuatnya di rumah masing-masing sesuai dengan tutorial yang sudah dibuat.

\section{DAFTAR PUSTAKA}

Ade Nasihudin. Liputan 6. 2020. https://www.liputan6.combola/read/4224174/ penjelasan-dokter-lula-kamal-soal-fungsimasker-kain-cegah-corona-covid-19.

Anon. 2018. Manfaat Super Jahe Merah untuk Kesehatan. https://www.republikaonline.

Biananda, B. 2020. https://kesehatan.kontan.co.id/news/masih-pandemitetap-rajin-cuci-tangan-tapi-dengan-cara-yang-benar?page= all.

Goulart, F.S. 1995. Super Healing Foods. Reward Books, a member of Penguin Putnam Inc. New York.

https://www.ugm.ac.id/id/berita/19207- berjemursinar-matahari-mampumeningkatkan-kekebalantubuh.

Kompas. 2020. "cegah corona, profesor Unair paparkan 8 cara tingkatkan imun".https://edukasi.kompas.com/read/2020/03/22/164500371/ceg ah-corona-profesorunair-paparkan-8-cara-tingkatkan-imuntubuh.

Leach, J. 2017. 11 Proven Health Benefits of Ginger. https://www.healthline.com/nutrition/

Mona, N. 2020. Konsep Isolasi dalam Jaringan Sosial untuk Meminimalisasi Efek Contagius (Kasus Penyebaran Virus Corona di Indonesia). Jurnal Sosial Humaniora Terapan, 2(2); 117-125.

Nareza, Meva. 2020."cegah virus corona dengan memperkuat sistem imun". https://www.alodokter.com/cegah-viruscorona-denganmemperkuat-sistem-imuntubuh. 
TRIBUTE : JOURNAL OF COMMUNITY SERVICES

Vol.1, No. 1, Oktober 2020: 45-53

Suparyo. 2014. Manfaat Rempah Rempah Untuk Kesehatan. http://daunbuah.com/ manfaat-rempah-rempah-untuk-kesehatan.

Widiyani, R. 2020. Latar Belakang Virus Corona, Perkembangan hingga Isu Terkini. Retrieved from detikNews: https://news.detik.com/berita/d4943950/latar-belakang-viruscoronaperkembangan-hingga-isu-terkini

World Health Organization. (2019). Coronavirus. Retrieved from World Health Organization: https://www.who.int/healthtopics/coronavirus

Zendrato, W. 2020. Gerakan Mencegah Daripada Mengobati Terhadap Pandemi Covid-19. Journal Education and Development, 8(20); 242-248. 